\title{
Hygroscopic behavior of atmospherically relevant water-soluble carboxylic salts and their influence on the water uptake of ammonium sulfate
}

\author{
Z. J. Wu, A. Nowak, L. Poulain, H. Herrmann, and A. Wiedensohler \\ Leibniz Institute for Tropospheric Research, Permoserstr. 15, 04318 Leipzig, Germany \\ Received: 3 February 2011 - Published in Atmos. Chem. Phys. Discuss.: 7 March 2011 \\ Revised: 20 October 2011 - Accepted: 3 November 2011 - Published: 15 December 2011
}

\begin{abstract}
The hygroscopic behavior of atmospherically relevant water-soluble carboxylic salts and their effects on ammonium sulfate were investigated using a hygroscopicity tandem differential mobility analyzer (H-TDMA). No hygroscopic growth is observed for disodium oxalate, while ammonium oxalate shows slight growth (growth factor $=1.05$ at $90 \%)$. The growth factors at $90 \% \mathrm{RH}$ for sodium acetate, disodium malonate, disodium succinate, disodium tartrate, diammonium tartrate, sodium pyruvate, disodium maleate, and humic acid sodium salt are 1.79, 1.78, 1.69, 1.54, 1.29, $1.70,1.78$, and 1.19 , respectively. The hygroscopic growth of mixtures of organic salts with ammonium sulfate, which are prepared as surrogates of atmospheric aerosols, was determined. A clear shift in deliquescence relative humidity to lower RH with increasing organic mass fraction was observed for these mixtures. Above $80 \% \mathrm{RH}$, the contribution to water uptake by the organic salts was close to that of ammonium sulfate for the majority of investigated compounds. The observed hygroscopic growth of the mixed particles at $\mathrm{RH}$ above the deliquescence relative humidity of ammonium sulfate agreed well with that predicted using the ZdanovskiiStokes-Robinson (ZSR) mixing rule. Mixtures of ammonium sulfate with organic salts are more hygroscopic than mixtures with organic acids, indicating that neutralization by gas-phase ammonia and/or association with cations of dicarbonxylic acids may enhance the hygroscopicity of the atmospheric particles.
\end{abstract}

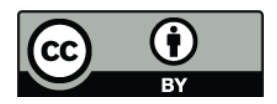

Correspondence to: $\mathrm{Z}$. J. Wu (wuzhijun@tropos.de)

\section{Introduction}

In the atmosphere, aerosol hygroscopicity plays an important role in cloud formation, visibility degradation, and atmospheric chemistry (Pandis et al., 1995; Sloane and Wolff, 1985; McFiggans et al., 2006). The effects of inorganic salts commonly found in atmospheric aerosols on particle hygroscopic properties are well characterized nowadays. However, knowledge on the influence of water uptake of the organic aerosol fraction, which contributes $20-90 \%$ of atmospheric fine aerosol mass, still remains limited (Kanakidou et al., 2005; Zhang et al., 2007; Hallquist et al., 2009). A substantial portion of organic aerosols is water soluble organic matter (WSOM) (Saxena and Hildemann, 1996), including low molecular weight carboxylic acids (e.g. Kawamura and Gagosian, 1987; Legrand et al., 2007; Kawamura et al., 1996) and macromolecular humic-like substances (HULIS) (Graber and Rudich, 2006), which can considerably influence the hygroscopic behavior of the inorganic aerosol (Decesari et al., 2003; Saxena and Hildemann, 1996; Choi and Chan, 2002). These organic acids may be neutralized by gas-phase ammonia and/or associate with cations such as sodium and potassium in the particle phase. Thereby organic salts are formed, which show rather different thermodynamic properties from their acids (Peng and Chan, 2001). Typically, sodium salts of organic acids can be found in marine aerosol particles (Kerminen et al., 1998). In other atmospheric environments, such as in the Amazon Basin, the aerosol ion balance calculation shows that with an excess of inorganic bases, gaseous organic acids can act to neutralize particles by forming organic salts (Mircea et al., 2005; Trebs et al., 2005; Metzger et al., 2006). Recently, the formation of organic salts such as aminium salts was proposed to be

Published by Copernicus Publications on behalf of the European Geosciences Union. 
a pathway for contribution of low molecular weight organic compounds to atmospheric nanoparticle growth (Barsanti et al., 2009; Smith et al., 2010; Ge et al., 2011a, b). Laboratory studies of the reactive uptake of ammonia onto slightly soluble organic acid particles found that this process can significantly increase the $\mathrm{CCN}$ activity and hygroscopic growth of these particles (Dinar et al., 2008; Mircea et al., 2005). These evidences indicate that organic salts instead of their acids might play important roles under certain circumstances in the atmosphere.

Previous laboratory studies, investigating the hygroscopicity of organic substances, mainly focused on organic acids using a H-TDMA or an electrodynamic balance (EDB) (Kanakidou et al., 2005). Conversely, the investigations on their salts are very sparse (Kanakidou et al., 2005). An investigation of the water cycles of water-soluble organic salts of atmospheric interests was performed by Peng and Chan (2001) using an EDB. Their results showed that sodium salts of formate, acetate, malonate, succinate, maleate, and pyruvate have a growth factor of 1.76-2.18 at a relative humidity (RH) of $90 \%$. The EDB method, however, is typically used for particles larger than a few micrometres in diameter and not suitable for studies of hygroscopic growth of fine atmospheric aerosol particles (Swietlicki et al., 2008). The hygroscopic growth of a sodium salt of humic acid $(\mathrm{GF}=1.08$ at $90 \% \mathrm{RH}$ ) has been determined using H-TDMA by several studies (e.g. Gysel et al., 2004), showing that it is slightly more hygroscopic than humic acid $(\mathrm{GF}=1.06$ at $90 \% \mathrm{RH})$. The effect of organic compounds on the hygroscopicity of atmospherically relevant inorganic salts were widely investigated in previous studies (e.g. Cruz and Pandis, 2000; Zardini et al., 2008; Choi and Chan, 2002; Marcolli and Krieger, 2006a; Topping et al., 2005; Svenningsson et al., 2006). Again, they mainly focused on the roles of organic acids.

In this study, we determine the hygroscopic growth of atmospherically relevant organic salts using the H-TDMA technique. Furthermore, their mixtures with ammonium sulfate, which is one of the most abundant inorganic constituents found in the atmosphere (Seinfeld and Pandis, 1998), are investigated to determine the influence of organic salts on the hygroscopic behavior of ammonium sulfate. In addition, we use the Zdanovskii-Stokes-Robinson (ZSR) method to predict the hygroscopic growth of mixtures based on the hygroscopicity of the individual compounds.

\section{Experiments}

\subsection{Instrumentation}

The hygroscopic growth of particles is investigated using a H-TDMA. The H-TDMA used in this study was employed in various field studies and is described in detail by Massling et al. (2003, 2007). Only a brief description is given here. The H-TDMA consists of three main parts: (1) a Differential Mo- bility Analyzer (DMA1) that selects quasi-monodisperse particles, and a Condensation Particle Counter (CPC1) that measures the particle number concentration leaving the DMA1 at the selected particle size; (2) an aerosol humidifier conditioning the particles selected by DMA1 to a defined relative humidity; (3) the second DMA (DMA2) coupled with another condensation particle counter (CPC2) to measure the number size distributions of the humidified aerosol.

To ensure the stability of the RHs, the proportionalintegral-derivative (PID) controlling method is utilized to regulate the RHs for both aerosol humidifier and sheath air of DMA2. In addition, DMA2 and aerosol humidifier are kept within a temperature-controlled box to avoid the temperature fluctuations higher than $0.3 \mathrm{~K}$. Capacitive RH sensors (Model HMP237, VAISALA Inc.) used to monitor the conditions in the H-TDMA are regularly calibrated against a dew point hygrometer (the same dew point hygrometer used to measure the RH in DMA2) during the measurements. $\mathrm{RH}$ for the aerosol humidifier is kept the same as the sheath air of DMA2 during the measurements. The experiments are conducted in the lab, in which the room temperature is airconditioned to be within $20 \pm 1^{\circ} \mathrm{C}$.

The residence time of particles at nominal RH (90\%) before entering into the DMA2 is around $2.5 \mathrm{~s}$ in our system. This residence time may be insufficient for some organic compounds to attain equilibrium state (Chan and Chan, 2005; Peng and Chan, 2001; Duplissy et al., 2009; Sjogren et al., 2007); for example, sodium pyruvate which needs a longer time to obtain equilibrium (Peng and Chan, 2001).

The hygroscopic growth factor (GF) is defined as the ratio of the particle mobility diameter, $D(\mathrm{RH})$, at a given $\mathrm{RH}$ to the dry diameter, $D_{\mathrm{d}}, 100 \mathrm{~nm}$ in this study:

$\mathrm{GF}(\mathrm{RH})=\frac{D(\mathrm{RH})}{D_{\mathrm{d}}}$.

The inversion of the H-TDMA data is based on TDMAinv method developed by Gysel et al. (2009). Dry scans (under $\mathrm{RH}<5 \%$ ) are used to calibrate any size shift between DMA1 and DMA2 and define the width of the HTDMA's transfer function (Gysel et al., 2009) for each compound being measured.

\subsection{Aerosol generation}

A nebulizer was used to generate particles from a solution of selected organic compounds as listed in the first column of Table 1 , diluted in ultra-pure water $\left(18.2 \mathrm{M} \Omega \mathrm{cm}\right.$ at $25^{\circ} \mathrm{C}$; Milli-Q Academic, Millipore, USA). Humic acid sodium salts cannot be completely dissolved in water. In order to remove the non-dissolved material, the solution was filtered through a paper filter with a $2 \mu \mathrm{m}$ pore size. The generated particles were dried by passing through a diffusion drier filled with silica gel, and then mixed with pure dry air in a glass mixing chamber. The RH of the sampling air flow was kept 
Table 1. Properties of salts being studied.

\begin{tabular}{lllll}
\hline Chemical compounds & Molecular formula & Molar Weight $\left[\mathrm{g} \mathrm{mol}^{-1}\right]$ & Density $\left[\mathrm{g} \mathrm{cm}^{-3}\right]$ & Solubility [g/100 ml] \\
\hline Ammonium sulfate & $\left(\mathrm{NH}_{4}\right)_{2} \mathrm{SO}_{4}$ & 132.14 & $1.77^{\mathrm{a}}$ & $74.4\left(20^{\circ} \mathrm{C}\right)^{\mathrm{e}}$ \\
Sodium acetate & $\mathrm{C}_{2} \mathrm{H}_{3} \mathrm{NaO}_{2}$ & 82.03 & $1.53^{\mathrm{a}}$ & $46.4\left(20^{\circ} \mathrm{C}\right)^{\mathrm{e}}$ \\
Disodium oxalate & $\mathrm{Na}_{2} \mathrm{C}_{2} \mathrm{O}_{4}$ & 134.00 & $2.34^{\mathrm{a}}$ & $3.7\left(20^{\circ} \mathrm{C}\right)^{\mathrm{e}}$ \\
Diammonium oxalate & $\mathrm{C}_{2} \mathrm{H}_{8} \mathrm{~N}_{2} \mathrm{O}_{4}$ & 124.10 & $1.50^{\mathrm{a}}$ & $4.45\left(20^{\circ} \mathrm{C}\right)^{\mathrm{e}}$ \\
Disodium malonate & $\mathrm{C}_{3} \mathrm{H}_{2} \mathrm{O}_{4} \mathrm{Na}_{2}$ & 148.03 & $1.75^{\mathrm{a}}$ & $59.06\left(25^{\circ} \mathrm{C}\right)^{\mathrm{f}}$ \\
Disodium succinate & $\mathrm{Na}_{2} \mathrm{C}_{4} \mathrm{H}_{4} \mathrm{O}_{4}$ & 162.05 & $1.68^{\mathrm{a}}$ & $39.70\left(25^{\circ} \mathrm{C}\right)^{\mathrm{f}}$ \\
Disodium tartrate & $\mathrm{C}_{4} \mathrm{H}_{4} \mathrm{Na}_{2} \mathrm{O}_{6}$ & 194.05 & $1.82^{\mathrm{b}}$ & $25\left(25^{\circ} \mathrm{C}\right)^{\mathrm{g}}$ \\
Diammonium tartrate & $\mathrm{C}_{4} \mathrm{H}_{12} \mathrm{~N}_{2} \mathrm{O}_{6}$ & 184.15 & $1.60^{\mathrm{c}}$ & $63\left(20^{\circ} \mathrm{C}\right)^{\mathrm{C}}$ \\
Sodium pyruvate & $\mathrm{C}_{3} \mathrm{H}_{3} \mathrm{NaO}_{3}$ & 110.00 & $1.54^{\mathrm{d}}$ & $47.5\left(20^{\circ} \mathrm{C}\right)^{\mathrm{h}}$ \\
Disodium maleate & $\mathrm{C}_{4} \mathrm{H}_{2} \mathrm{O}_{4} \mathrm{Na}_{2}$ & 160.04 & $1.79^{\mathrm{d}}$ & $96.0\left(25^{\circ} \mathrm{C}\right)^{\mathrm{i}}$ \\
Humic acid sodium salt & - & $2000-500000$ & - & $\mathrm{NA}$
\end{tabular}

${ }^{\text {a }}$ Broul et al. (1981); ${ }^{b}$ http://www.chemicalbook.com/ProductMSDSDetailCB3297454_EN.htm $\{\#\} 2 ;{ }^{c}$ http://www.guidechem.com/dictionary/3164-29-2.html; ${ }^{\text {d }}$ Peng and Chan (2001); ${ }^{\mathrm{e}}$ wiki soluble table; ${ }^{\mathrm{f}}$ Rozaini and Brimblecombe (2009); ${ }^{\mathrm{g}}$ http://www.thegoodscentscompany.com/data/rw1303591.html; ${ }^{\mathrm{h}}$ http://www.musashino.com/english/products/

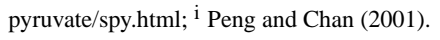

below $5 \%$ and monitored by a $\mathrm{RH}$ sensor mounted in the inlet of H-TDMA.

Hygroscopic growth of an ammonium sulfate aerosol was measured first to compare with the predicted growth using the parameterizations given by Tang and Munkelwitz (1994) and thus to validate the accuracy and performance of the $\mathrm{H}$ TDMA. Afterwards, the hygroscopic GFs of the organic salts were determined. All salts being studied are the products of Sigma-Aldrich Company (www.sigmaaldrich.com). The purity of reagent was greater than or equal to $99 \%$. The information on the properties of these salts is given in Table 1.

\subsection{Measurement uncertainty}

The measurement uncertainty of H-TDMA depends mainly on the accuracy in RH within the system but also on a possible size shift between the two DMAs (Massling et al., 2007). The particle size shift between DMA1 and DMA2 for the entire data set was calibrated using the dry scans (non-humidified particle sizing). The estimated uncertainty in measurements between $30 \%$ and $90 \% \mathrm{RH}$ was $\pm 1 \% \mathrm{RH}$. Correspondingly, this uncertainty results in a relative uncertainty of around $2.5 \%$ for GFs of ammonium sulfate particles measured at $90 \%$ RH (Massling et al., 2003).

\subsection{Data evaluation}

Water activity $\left(a_{\mathrm{w}}\right)$ was calculated from the relative humidity and used in the following analysis to minimize the effect of particle size:

$a_{\mathrm{w}}=\frac{\mathrm{RH}}{\exp \left(\frac{4 \sigma_{\mathrm{s} / \mathrm{a}} M_{\mathrm{water}}}{R T \rho_{\mathrm{water}} D_{\mathrm{wet}}}\right)}$

where, $\sigma_{\mathrm{s} / \mathrm{a}}, M_{\text {water }}, R, T, \rho_{\text {water }}$, and $D_{\text {wet }}$ are the surface tension, the molecular weight of water, the universal gas con- stant, temperature, the density of water, and the droplet diameter, respectively. $D_{\text {wet }}$ is the product of GF and the diameter of dry particle $\left(D_{\text {dry }}\right)$. As an approximation, the Kelvin effect is defined for pure water.

An equation proposed by Dick et al. (2000) is used to perform the fitting to present the relationship between water activity and GFs of individual compounds:

$\mathrm{GF}=\left[1+\left(a+b a_{\mathrm{w}}+c a_{\mathrm{w}}^{2}\right) \frac{a_{\mathrm{w}}}{1-a_{\mathrm{w}}}\right]^{1 / 3}$

The van't Hoff factor $i$ is used to describe dissociation and non-ideality effects in a solution. McDonald (1953) and Low (1969) introduced a general extension of Raoult's law with the van't Hoff factor:

$a_{\mathrm{w}}=\frac{n_{\mathrm{water}}}{n_{\mathrm{water}}+i n_{\mathrm{s}}}=\frac{1}{1+i M_{\mathrm{water}} m_{\mathrm{s}}}$

Here, $n_{\text {water }}$ and $n_{\mathrm{s}}$ is the number of moles of water and solute, respectively. The molality of the solute $m_{\mathrm{s}}$ can be presented as (Svenningsson et al., 2006):

$$
\begin{aligned}
m_{\mathrm{s}} & =\frac{n_{\mathrm{s}}}{\operatorname{mass}_{\text {water }}}=\frac{\rho_{\mathrm{s}} \frac{\pi}{6} D_{\text {dry }}^{3} / M_{\mathrm{s}}}{\rho_{\text {water } \frac{\pi}{6}}\left(D_{\text {wet }}^{3}-D_{\text {dry }}^{3}\right)} \\
& =\frac{\rho_{\mathrm{s}}}{M_{\mathrm{s}} \rho_{\text {water }}\left(\mathrm{GF}^{3}-1\right)}
\end{aligned}
$$

where $\rho_{\mathrm{s}}$ and $M_{\mathrm{s}}$, respectively, are the density and molecular weight of the solute. Here, we assume that water and solute volumes are additive. Because the dry particle volume as a whole is involved in the calculation, this equation is valid only when/after the dry particle is completely dissolved in the water. The threshold of GF and corresponding $a_{\mathrm{w}}$ at which a dry particle is fully dissolved can be identified when the calculated molality using Eq. (4) is equal to the solubility 
Table 2. The fitting parameters of the growth curve parametrization and Van't Hoff factor.

\begin{tabular}{lrrrrr}
\hline & & & & & Van't Hoff \\
Salts & $a_{\mathrm{W}}$ & $a$ & $b$ & $c$ & Factor/ideal \\
\hline Ammonium sulfate & $0.8-0.9$ & 0.23018 & 0.92875 & -0.7282 & $2.04 / 3$ \\
Sodium acetate & $0.4-0.9$ & 0.51418 & 0.67867 & -0.65864 & $1.80 / 2$ \\
Disodium oxalate & - & - & - & - & - \\
Diammonium oxalate & - & - & - & - & - \\
Disodium malonate & $0.2-0.9$ & -0.25346 & 3.20915 & -2.5515 & $2.95 / 3$ \\
Disodium succinate & $0.2-0.9$ & -0.11095 & 3.25171 & -2.92462 & - \\
Disodium tartrate & $0.2-0.9$ & -0.52175 & 2.19924 & -1.38076 & - \\
Diammonium tartrate & $0.2-0.9$ & -0.01105 & 0.3971 & -0.236 & - \\
Sodium pyruvate & $0.8-0.9$ & 0.66856 & -0.45491 & 0.28678 & $1.95 / 2$ \\
Disodium maleate & $0.1-0.9$ & -0.31807 & 3.41428 & -2.69608 & $3.30(2.94) / 3$ \\
Humic acid sodium salt & $0.1-0.9$ & 0.10856 & 0.28154 & -0.33565 & - \\
\hline
\end{tabular}

of organic salt. Afterwards, the GFs larger than this threshold will be used in the calculation of van't Hoff factor, $i$ :

$i=\left(a_{\mathrm{w}}^{-1}-1\right)\left(\mathrm{GF}^{3}-1\right) \frac{M_{\mathrm{s}} \rho_{\text {water }}}{M_{\text {water }} \rho_{\mathrm{s}}}$

The mean van't Hoff factors of ammonium sulfate, sodium acetate, disodium malonate, disodium maleate, and sodium pyruvate were calculated and listed in Table 2.

Based on the ZSR method (Stokes and Robinson, 1966), the GF of a mixture $\left(\mathrm{GF}_{\text {mixed }}\right)$ can be estimated from the $\mathrm{GF}_{i}$ of the pure components and their respective volume fractions, $\varepsilon_{i}$ (Malm and Kreidenweis, 1997):

$\mathrm{GF}_{\text {mixed }}=\left(\sum_{i} \varepsilon_{i} \mathrm{GF}_{i}^{3}\right)^{1 / 3}$

Here, $\varepsilon_{i}$ are calculated from mass fractions, $w_{i}$, of component $i$ in the mixture with the assumption of no change in the volume after compounds are mixed:

$\varepsilon_{i}=\frac{w_{i} / \rho_{i}}{\sum_{k}\left(w_{k} / \rho_{k}\right)}$

In this equation, the denominator means the total volume of mixture.

\section{Results and discussion}

\subsection{Pure organic salts}

The GFs of $100 \mathrm{~nm}$ organic salt particles as a function of water activity are presented in Fig. 1. They are parameterized using Eq. (3), and the fitting parameters are summarized in Table 2. In Table 3, the GFs at $90 \%$ of organic salts and their deliquescence relative humidity (DRH) found in other publications are listed to make comparisons with this study.

\subsubsection{Sodium acetate}

As shown in Fig. 1a, DRH of sodium acetate is around $40 \%$ (39-42\%), which is slightly lower than that (43.5-45.2\%) observed by Peng and Chan (2001) using an EDB. This discrepancy may be caused by the measurement error with uncertainty of $\pm 1 \% \mathrm{RH}$ and the difference in detection methods.

The GF of sodium acetate at $90 \%$ is 1.79 , which is much lower than that (1.91) measured by Peng and Chan (2001). This discrepancy may be caused by the difference in the residence time between two studies as mentioned above. Additionally, the amount of water molecules containing in the atomizer-generated sub-micrometer particles may be different from that of crystals formed from bulk solutions in Peng and Chan's (2001) study. Previous lab studies showed that the residual water molecules in the particles may introduce the biases in the measured aerosol thermodynamic parameters (Cappa et al., 2007; Rissman et al., 2007). Other factors, such as the particle size, detection methods, and measurement uncertainty, could also contribute to this difference. The van't Hoff factor is estimated as 1.8, which is much lower than the number of discrete ions (2) at ideal conditions.

\subsubsection{Disodium oxalate and diammonium oxalate}

Disodium oxalate has a low solubility $(3.7 \mathrm{~g} / 100 \mathrm{ml}$ water at $20^{\circ} \mathrm{C}$ ). No hygroscopic growth was observed below $90 \%$ $\mathrm{RH}$, as shown in Fig. 1b. This is consistent with the previous results from the EDB (Peng and Chan, 2001) and H-TDMA (Mensah et al., 2009) measurements. Mensah et al. (2009) observed that disodium oxalate particles start to take up water above $92.2 \% \mathrm{RH}$.

Similar to disodium oxalate, the solubility of diammonium oxalate $\left(4.45 \mathrm{~g} / 100 \mathrm{ml}\right.$ water at $\left.20^{\circ} \mathrm{C}\right)$ is very low. Below $30 \% \mathrm{RH}$, no growth is observed. Above this RH, the GF is constant and around 1.05. This hygroscopic behavior is in agreement with that observed using H-TDMA by Mensah 

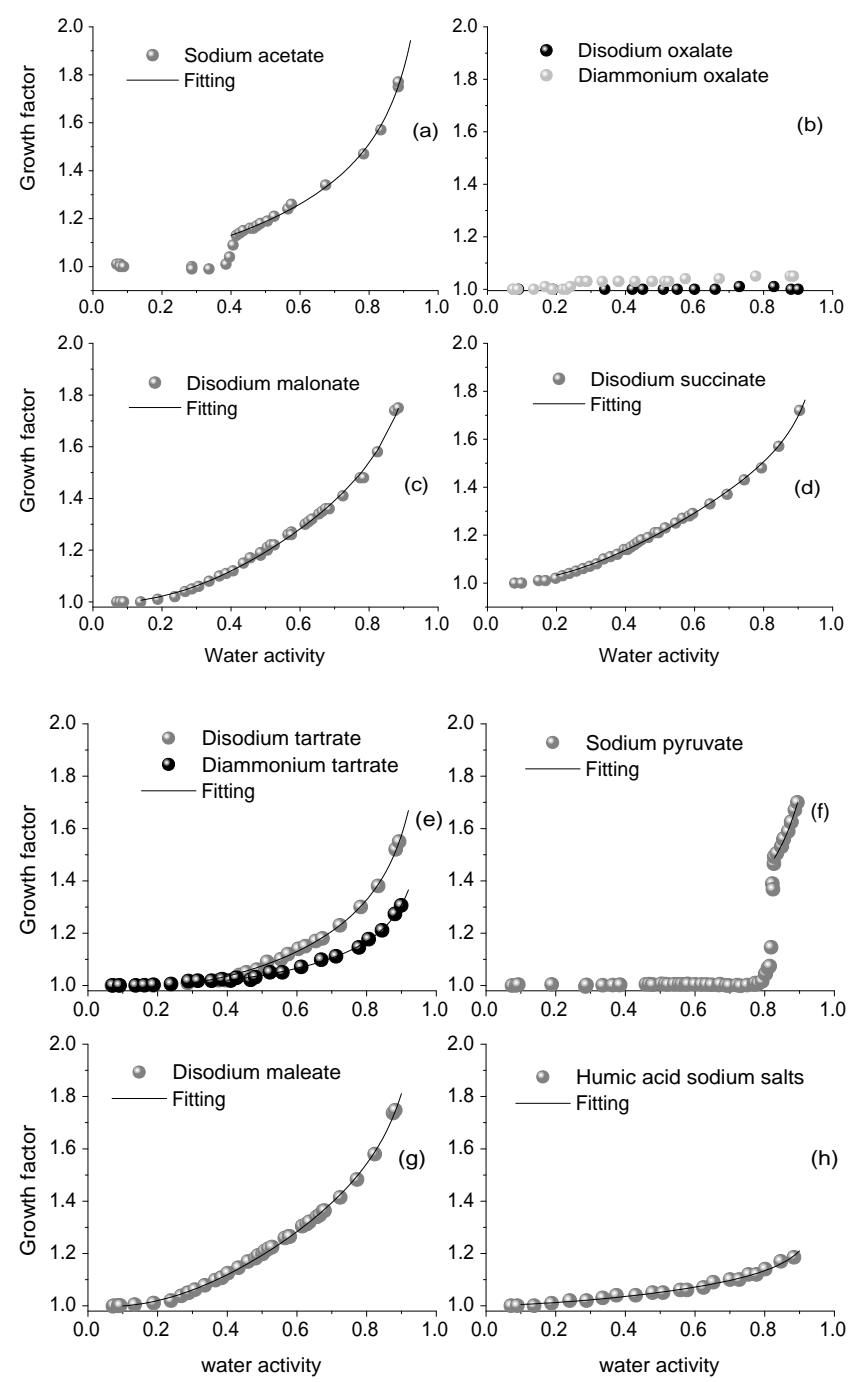

Fig. 1. Hygroscopic growth factors of organic salts as a function of water activity.

et al. (2009) below $90 \%$. Their results show that DRH of diammonium oxalate is $93.3 \%$. The GF of the corresponding organic acid, oxalic acid, reported in a previous study is given in the Table 3. At $90 \%$, oxalic acid does not take up any water.

\subsubsection{Disodium malonate}

As shown in Fig. 1c), disodium malonate continues to grow with increasing RH, and no deliquescence point is observed, similar to the behavior reported by Peng and Chan (2001). The GF at $90 \%$ is 1.78 , which is equal to that reported in the literature. In contrast to the disodium malonate, malonic acid with GF of 1.48 at $90 \%$ is less hygroscopic. The van't Hoff factor is 2.95 at water activity between 0.82 and 0.9 .

\subsubsection{Disodium succinate}

Similar to disodium malonate, no deliquescence point is observed for disodium succinate, as shown in Fig. 1d. This is different from the observation using an EDB by Peng and Chan (2001), whose result shows the DRH is $63.5-66 \%$. The solubility of disodium succinate is strongly temperaturedependent (Rozaini and Brimblecombe, 2009). The difference in temperature at which the measurement was performed between two studies may cause this discrepancy in DRH determination. In addition, the impurity of solution being measured may be another possible reason. In contrast to disodium succinate, succinic acid is hydrophobic at $90 \%$ because its deliquescence point is found at $99 \%$ (Wex et al., 2007).

\subsubsection{Disodium tartrate and diammonium tartrate}

The hygroscopic growths for disodium tartrate and diammonium tartrate are presented in Fig. 1e. Both salts continue to grow above $40 \% \mathrm{RH}$. The sodium salt is more hygroscopic than the ammonium salt. The GFs of disodium tartrate and diammonium tartrate are 1.54 and 1.29 at $90 \%$, respectively. The tartaric acid with a GF of 1.39 is less hygroscopic than disodium tartrate, but higher than diammonium tartrate.

\subsubsection{Sodium pyruvate}

The DRH of sodium pyruvate is around $82 \%$, which is within the DRH (71.6-83.9\%) observed by Peng and Chan (2001). In Peng and Chan's study, they observed that sodium pyruvate shows a gradual deliquescence process and kept absorbing water at $\mathrm{RH}=79 \%$ even after $11 \mathrm{~h}$. They ascribed it to the internal mass transfer limitation of the particle during growth. This behavior cannot be observed using the HTDMA system. As mentioned above, the residence time in the HTDMA system is much shorter. Within this residence time, sodium pyruvate may not have enough time to attain equilibrium at $90 \%$. This may explain the lower GF $(\mathrm{GF}=1.70)$ in this study in contrast to Peng and Chan's 2001 study $(\mathrm{GF}=1.76)$. The GF of pyruvic acid is not found in the literature. The mean van't Hoff factor is 1.95 between $a_{\mathrm{w}}=0.82$ and 0.9 .

\subsubsection{Disodium maleate}

As shown in Fig. 1g, disodium maleate particles start to grow at $\mathrm{RH}$ above $20 \%$. Afterwards, particles continuously take up water with the increasing $\mathrm{RH}$. The GF at $90 \%$ is 1.78 , which is slightly higher than that (1.76) reported by Peng and Chan (2001). The Malei acid with GF $=1.51$ is less hygroscopic than its salt.

The water activity at which the particle completely dissolved is 0.82 . The mean van't Hoff factor at $a_{\mathrm{w}}=0.82-0.9$ is 3.30, which is significantly larger than the number of discrete ions under ideal conditions. The possible reason is that 
Table 3. Comparisons of GFs (90\% RH) and DRH between this study and previous studies as well as organic acids.

\begin{tabular}{lllllll}
\hline Salts & $\begin{array}{l}\text { GF }(90 \%) \\
\text { This study }\end{array}$ & $\begin{array}{l}\text { GF }(90 \%) \\
\text { In literature }\end{array}$ & $\begin{array}{l}\text { DRH } \\
\text { This study }\end{array}$ & $\begin{array}{l}\text { DRH } \\
\text { literature }\end{array}$ & $\begin{array}{l}\text { Organic } \\
\text { acid }\end{array}$ & $\begin{array}{l}\text { GF (90\%) } \\
\text { literature }\end{array}$ \\
\hline Ammonium sulfate & 1.70 & $1.67-1.72^{\mathrm{a}}$ & $77-78 \%$ & $80 \%$ & & \\
Sodium acetate & 1.79 & $1.91^{\mathrm{b}}$ & $39-42 \%$ & $43.5-45.2 \%$ & acetic acid & $\mathrm{NF}$ \\
Disodium oxalate & 1.00 & $1.0^{\mathrm{b}}$ & - & - & oxalic acid & $1.00^{\mathrm{d}}$ \\
Diammonium oxalate & 1.05 & $1.0^{\mathrm{b}}$ & & - & - & - \\
Disodium malonate & 1.78 & $1.78^{\mathrm{b}}$ & - & - & malonic acid & $1.48^{\mathrm{d}}$ \\
Disodium succinate & 1.69 & $1.85^{\mathrm{b}}$ & $\mathrm{NO}$ & $63.5-66 \% \mathrm{~b}$ & Succinic acid & $1.00^{\mathrm{d}}$ \\
Disodium tartrate & 1.54 & $\mathrm{NF}$ & - & - & tartaric acid & $1.39^{\mathrm{e}}$ \\
Diammonium tartrate & 1.29 & $\mathrm{NF}$ & - & - & - & - \\
Sodium pyruvate & 1.70 & $1.76^{\mathrm{b}}$ & $81-82 \%$ & $71.6-83.9 \%$ & Pyruvic acid & $\mathrm{NF}$ \\
Disodium maleate & 1.78 & $1.76^{\mathrm{b}}$ & - & - & Maleic acid & $1.51^{\mathrm{d}}$ \\
Humic acid sodium salt & 1.19 & $1.18^{\mathrm{c}}$ & $\mathrm{NO}$ & $60-75 \% \mathrm{c}$ & Humic acid & $1.06^{\mathrm{c}}$ \\
\hline
\end{tabular}

${ }^{a}$ Duplissy et al. (2009); ${ }^{\mathrm{b}}$ Peng and Chan (2001); ${ }^{\mathrm{c}}$ Gysel et al. (2004); ${ }^{\mathrm{d}}$ Wise et al. (2003); ${ }^{\mathrm{e}}$ Peng et al. (2001). NF: not found, NO: not observed.

the particle volume after absorbing water is smaller than the addition of dry particle and water volume. This leads to an underestimation of molality using Eq. (4). Thus, the water activity at which the dry particle completely dissolves is underestimated and should be higher than 0.82. Above water activity $=0.88$, the van't Hoff factor is lower than 3, and mean value at $a_{\mathrm{w}}=0.88-0.9$ is 2.94 .

\subsubsection{Humic acid sodium salts}

The hygroscopic growth of humic acid sodium salts has been investigated by several previous laboratory studies (Badger et al., 2006; Gysel et al., 2004; Hatch et al., 2009). Gysel et al. (2004) observed that humic acid sodium salts deliquesce at RH between $60-75 \%$. Whereas, no deliquescence behavior is found by Badger et al. (2006)'s study. Similarly, our observation, as displayed in Fig. 1h, shows that the humic acid sodium salts particles continuously grow with increasing RH.

\subsection{Mixtures of organic salts with $\left(\mathrm{NH}_{4}\right)_{2} \mathrm{SO}_{4}$}

Three mixtures are investigated to determine the influences of organic salts on the hygroscopicity of ammonium sulfate. These mixtures are prepared according to the chemical composition of the atmospheric particles reported in the literature assuming carboxylic salts instead of carboxylic acids in the atmospheric aerosols. Oxalic acid is assumed to neutralize by ammonia, i.e. forming ammonium oxalate, and others are assumed as sodium salts. Their chemical compositions are given in Table 4. Mix_urb, Mix_mar, and Mix_bio represent urban aerosols in Hong Kong (Yao et al., 2004), marine aerosols in Mace Head (Kleefeld et al., 2002), and biomass burning aerosols in Brazil (Kundu et al., 2010a, b), respectively.

\subsubsection{Effect of organic salts on the deliquescence}

The humidograms of mixtures and pure ammonium sulfate are shown in Fig. 2. There is a clear shift in DRH to lower $\mathrm{RH}$ with increasing organic mass fraction, indicating that these organic salts have significant effects on the deliquescence of ammonium sulfate. With increasing organic mass fraction, a smoothing of the deliquescence behavior is observed. This phenomenon was also observed for mixtures of ammonium sulfate and individual dicarboxylic acids such as citric acid, succinic acid, and malonic acid by previous studies (e.g. Zardini et al., 2008; Hameri et al., 2002; Marcolli and Krieger, 2006b). Ling and Chan (2008) and Yeung and Chan (2010) investigated partial deliquescence of AS and dicarboxylic acids mixtures using an EDB and a Raman spectrometer. They observed that malonic acid with lower DRH contributed to the taking up of water at low RH; deliquescence of ammonium sulfate gradually took place starting from $69 \% \mathrm{RH}$, then the mixture completely deliquescent at $75 \%$. Some organic acids, including glutaric, pinonic, adipic, and phthalic acids, with low water solubility show no influence on the deliquescence behavior of ammonium sulfate (Cruz and Pandis, 2000; Hameri et al., 2002).

The deliquescence behavior of Mix_urb with $3.04 \%$ organic mass fraction is similar to that of pure ammonium sulfate. Its DRH (around $78 \pm 1 \%$ ) is slightly lower than that of pure ammonium sulfate (around $79 \pm 1 \%$ ).

Mix_mar particles start to take up water at $53 \% \mathrm{RH}$ and deliquesce completely around $73 \%$. In contrast to pure ammonium sulfate, the lower DRH $(73 \% \pm 1 \%)$ of Mix_mar indicates that ammonium sulfate in the mixture starts to take up some water before reaching its deliquescence point. Surprisingly, below $53 \%$ RH, Mix_mar (which contains $8.75 \%$ disodium malonate) shows no growth; however, pure disodium malonate gradually takes up water at the whole range of $\mathrm{RH}$ 
Table 4. The chemical composition of mixtures, mass percentage, wt $\%$.

\begin{tabular}{lrrrrrr}
\hline No. & $\begin{array}{r}\text { Ammonium } \\
\text { Sulfate }\end{array}$ & $\begin{array}{r}\text { Diammonium } \\
\text { oxalate }\end{array}$ & $\begin{array}{r}\text { Disodium } \\
\text { malonate }\end{array}$ & $\begin{array}{r}\text { Disodium } \\
\text { succinate }\end{array}$ & $\begin{array}{r}\text { Sodium } \\
\text { pyruvic }\end{array}$ & $\begin{array}{r}\text { Disodium } \\
\text { maleate }\end{array}$ \\
\hline Mix_urb & $96.96 \%$ & $2.39 \%$ & $0.20 \%$ & $0.45 \%$ & - & - \\
Mix_mar & $78.67 \%$ & $12.59 \%$ & $8.75 \%$ & - & - & - \\
Mix_bio & $58.28 \%$ & $28.84 \%$ & $4.35 \%$ & $7.67 \%$ & $0.51 \%$ & $0.35 \%$ \\
\hline
\end{tabular}
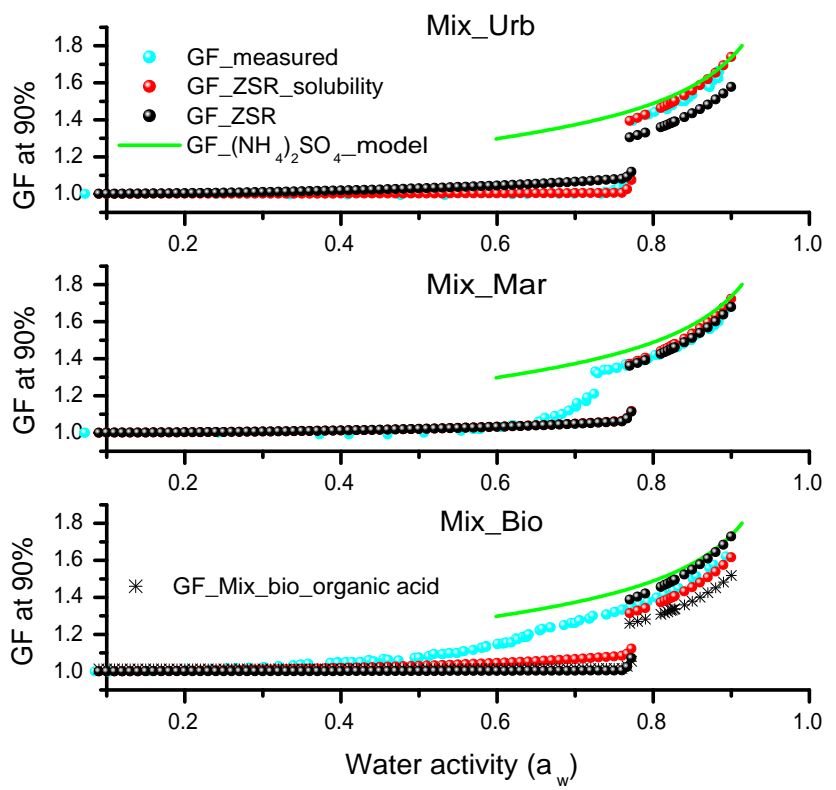

Fig. 2. The growth factors $(\mathrm{GF})$ of mixtures and modeled $\left(\mathrm{NH}_{4}\right)_{2} \mathrm{SO}_{4}$ versus water activity $\left(a_{\mathrm{W}}\right)$.

(ref. Fig. 1c). A possible explanation is that disodium malonate may be partly enclosed by ammonium sulfate, the dominant component in the mixture, which depresses its water uptake at lower RH.

Mix_bio particles start to absorb water vapor above $20 \%$ $\mathrm{RH}$ and deliquescent at around $66 \%$. Below its DRH, Mix_bio behaves similarly to those of pure disodium malonate and disodium succinate, i.e. taking up water gradually with increasing $\mathrm{RH}$.

\subsubsection{Comparison with theoretical predictions}

The differences in GFs of Mix_urb with low organic mass fraction and ammonium sulfate are not obvious above their DRHs. For Mix_mar and Mix_bio, GFs above RH=80\% are slightly lower than, but quite close to, those of pure ammonium sulfate, as shown in Fig. 2. This observation implies that the major fraction of organic salt in these particles should contribute to the water uptake close to that of ammonium sulfate.
The GFs of mixtures are predicted using the ZSR method with/without taking the solubility of ammonium oxalate into account. The results are shown in Fig. 2. If the contribution to the water uptake by ammonium oxalate is included, the GFs predicted by ZSR are closer to those measured by $\mathrm{H}-$ TDMA than without considering its solubility. A previous study (e.g. Svenningsson et al., 2006) also reported that the ZSR mixing rule can better predict the GF of a mixture with a slightly soluble component when the limited solubility is taken into account.

As shown in Fig. 2, the ZSR predictions agree very well with experimental results above the DRH of ammonium sulfate. However, the ZSR calculations underestimate the water uptake of mixture below the DRH. The similar results were also reported by Zardini et al. (2008). They showed that the hygroscopicity of mixtures of ammonium sulfate and glutaric acid is well described by the ZSR relationship as long as the two-component particle is completely liquid. In fact, the lower DRH of a mixture identified by H-TDMA measurements indicates that ammonium sulfate starts take up of water before full deliquescence. This phenomenon was also experimentally observed using an EDB and a Raman spectrometer (Ling and Chan, 2008; Yeung and Chan, 2010). In the simple mixing rule, it is assumed that ammonium sulfate absorb water until RH reached the DRH. This must underpredict the hygroscopic growth of mixture at lower RH. In previous studies on inorganic and organic mixtures, the ZSR model was found to be useful in predicting the water activity of the mixtures and the growth ratios (e.g. Cruz and Pandis, 2000; Gysel et al., 2004; Svenningsson et al., 2006). However, the detailed deliquescence behaviors of the organic/inorganic mixtures cannot be easily predicted from the hygroscopic properties of the individual components (Choi and Chan, 2002).

In order to compare the effects of organic salts and their acids on the hygroscopic growth on ammonium sulfate, the GF of Mix_bio_acid is calculated using the ZSR method and shown in Fig. 2. The Mix_bio_acid consists of ammonium sulfate, oxalic acid, malonic acid, succinic acid, maleic acid, and sodium pyruvate (Here, the GF of pyruvic acid is not found in the literature). The GF of the individual dicarboxylic acid over the whole range of water activity are calculated according to Table 3 and Eq. (5) in Wise et al. (2003). The volume fraction of individual organic acids is the same 
with Mix_bio. The GF of Mix_bio_acid is lower than that of Mix_bio above the DRH of ammonium sulfate. This implies that if the water soluble organic acids in the atmospheric aerosol are neutralized by ammonium or metal ions, the particle hygroscopicity will be enhanced.

\section{Summary}

The hygroscopic behavior of the atmospherically relevant organic salts and their mixtures with ammonium sulfate are characterized using a H-TDMA in this study. The DRHs for sodium acetate and sodium pyruvate are around $40 \%$ and $82 \%$, respectively. Other organic salts, including disodium malonate, disodium succinate, disodium tartrate, diammonium tartrate, disodium maleate, and humic acid sodium salt, take up water continuously with increasing RH. No hygroscopic growth is observed for disodium oxalate, while diammonium oxalate shows only a slight growth.

The mixtures of organic salts with ammonium sulfate, which are prepared simulating the atmospheric aerosols, are determined. The results show that organic salts have significant effects on the deliquescence of ammonium sulfate. With increasing organic mass fraction, a clear shift in DRH to lower RH, as well as a smoothing of the deliquescence behavior, are observed. Above $80 \% \mathrm{RH}$, the humidograms of mixtures are quite close to that of pure ammonium sulfate, implying that the major fraction of organic salt in these particles should contribute to the water uptake close to that of ammonium sulfate. The predictions using the ZSR relationship show a much better agreement with those derived from H-TDMA measurements above the DRH of ammonium sulfate. The lower hygroscopic growth of a mixture with organic acids indicates that neutralization of gas-phase ammonia and/or association with cations of dicarbonxylic acids may enhance the hygroscopicity of the atmospheric particles.

Acknowledgements. Here, we thank Heike Wex in the cloud group of Leibniz Institute for Tropospheric Research for the useful discussion.

Edited by: M. Gysel

\section{References}

Badger, C. L., George, I., Griffiths, P. T., Braban, C. F., Cox, R. A., and Abbatt, J. P. D.: Phase transitions and hygroscopic growth of aerosol particles containing humic acid and mixtures of humic acid and ammonium sulphate, Atmos. Chem. Phys., 6, 755-768, doi:10.5194/acp-6-755-2006, 2006.

Barsanti, K. C., McMurry, P. H., and Smith, J. N.: The potential contribution of organic salts to new particle growth, Atmos. Chem. Phys., 9, 2949-2957, doi:10.5194/acp-9-2949-2009, 2009.

Broul, M., Nyvlt, J., and Sohnel, O.: Solubility in inorganic twocomponent systems: Physical sciences data, Elsevier, Amsterdam, 6, 1981.
Cappa, C. D., Lovejoy, E. R., and Ravishankara, A. R.: Determination of evaporation rates and vapor pressures of very low volatility compounds: A study of the c-4-c-10 and c-12 dicarboxylic acids, J. Phys. Chem. A, 111, 3099-3109, 2007.

Chan, M. N. and Chan, C. K.: Mass transfer effects in hygroscopic measurements of aerosol particles, Atmos. Chem. Phys., 5, 2703-2712, doi:10.5194/acp-5-2703-2005, 2005.

Choi, M. Y. and Chan, C. K.: The effects of organic species on the hygroscopic behaviors of inorganic aerosols, Environ. Sci. Technol., 36, 2422-2428, doi:10.1021/es0113293, 2002.

Cruz, C. N. and Pandis, S. N.: Deliquescence and hygroscopic growth of mixed inorganic-organic atmospheric aerosol, Environ. Sci. Technol., 34, 4313-4319, 2000.

Decesari, S., Facchini, M. C., Mircea, M., Cavalli, F., and Fuzzi, S.: Solubility properties of surfactants in atmospheric aerosol and cloud/fog water samples, J. Geophys. Res.-Atmos., 108, 4685, doi:10.1029/2003JD003566, 2003.

Dick, W. D., Saxena, P., and McMurry, P. H.: Estimation of water uptake by organic compounds in submicron aerosols measured during the southeastern aerosol and visibility study, J. Geophys. Res., 105, 1471-1479, 2000.

Dinar, E., Anttila, T., and Rudich, Y.: Cen activity and hygroscopic growth of organic aerosols following reactive uptake of ammonia, Environ. Sci. Technol., 42, 793-799, 2008.

Duplissy, J., Gysel, M., Sjogren, S., Meyer, N., Good, N., Kammermann, L., Michaud, V., Weigel, R., Martins dos Santos, S., Gruening, C., Villani, P., Laj, P., Sellegri, K., Metzger, A., McFiggans, G. B., Wehrle, G., Richter, R., Dommen, J., Ristovski, Z., Baltensperger, U., and Weingartner, E.: Intercomparison study of six HTDMAs: results and recommendations, Atmos. Meas. Tech., 2, 363-378, doi:10.5194/amt-2-363-2009, 2009.

Ge, X., Wexler, A. S., and Clegg, S. L.: Atmospheric amines - part ii. Thermodynamic properties and gas/particle partitioning, Atmos. Environ., 45, 561-577, doi:10.1016/j.atmosenv.2010.10.013, 2011a.

Ge, X., Wexler, A. S., and Clegg, S. L.: Atmospheric amines - part i. A review, Atmos. Environ., 45, 524-546, doi:10.1016/j.atmosenv.2010.10.012, 2011b.

Graber, E. R. and Rudich, Y.: Atmospheric HULIS: How humiclike are they? A comprehensive and critical review, Atmos. Chem. Phys., 6, 729-753, doi:10.5194/acp-6-729-2006, 2006.

Gysel, M., Weingartner, E., Nyeki, S., Paulsen, D., Baltensperger, U., Galambos, I., and Kiss, G.: Hygroscopic properties of water-soluble matter and humic-like organics in atmospheric fine aerosol, Atmos. Chem. Phys., 4, 35-50, doi:10.5194/acp-4-352004, 2004.

Gysel, M., McFiggans, G. B., and Coe, H.: Inversion of tandem differential mobility analyser (tdma) measurements, J. Aerosol Sci., 40, 134-151, 2009.

Hallquist, M., Wenger, J. C., Baltensperger, U., Rudich, Y., Simpson, D., Claeys, M., Dommen, J., Donahue, N. M., George, C., Goldstein, A. H., Hamilton, J. F., Herrmann, H., Hoffmann, T., Iinuma, Y., Jang, M., Jenkin, M. E., Jimenez, J. L., Kiendler-Scharr, A., Maenhaut, W., McFiggans, G., Mentel, Th. F., Monod, A., Prévôt, A. S. H., Seinfeld, J. H., Surratt, J. D., Szmigielski, R., and Wildt, J.: The formation, properties and impact of secondary organic aerosol: current and emerging issues, Atmos. Chem. Phys., 9, 5155-5236, doi:10.5194/acp-95155-2009, 2009. 
Hameri, K., Charlson, R., and Hansson, H. C.: Hygroscopic properties of mixed ammonium sulfate and carboxylic acids particles, Aiche Journal, 48, 1309-1316, 2002.

Hatch, C. D., Gierlus, K. M., Zahardis, J., Schuttlefield, J., and Grassian, V. H.: Water uptake of humic and fulvic acid: Measurements and modelling using single parameter kohler theory, Environ. Chem., 6, 380-388, 2009.

Kanakidou, M., Seinfeld, J. H., Pandis, S. N., Barnes, I., Dentener, F. J., Facchini, M. C., Van Dingenen, R., Ervens, B., Nenes, A., Nielsen, C. J., Swietlicki, E., Putaud, J. P., Balkanski, Y., Fuzzi, S., Horth, J., Moortgat, G. K., Winterhalter, R., Myhre, C. E. L., Tsigaridis, K., Vignati, E., Stephanou, E. G., and Wilson, J.: Organic aerosol and global climate modelling: a review, Atmos. Chem. Phys., 5, 1053-1123, doi:10.5194/acp-5-1053-2005, 2005.

Kawamura, K. and Gagosian, R. B.: Implications of omegaoxocarboxylic acids in the remote marine atmosphere for photooxidation of unsaturated fatty-acids, Nature, 325, 330-332, 1987.

Kawamura, K., Semere, R., Imai, Y., Fujii, Y., and Hayashi, M.: Water soluble dicarboxylic acids and related compounds in antarctic aerosols, J. Geophys. Res.-Atmos., 101, 18721-18728, 1996.

Kerminen, V. M., Teinila, K., Hillamo, R., and Pakkanen, T.: Substitution of chloride in sea-salt particles by inorganic and organic anions, J. Aerosol Sci., 29, 929-942, 1998.

Kleefeld, S., Hoffer, A., Krivacsy, Z., and Jennings, S. G.: Importance of organic and black carbon in atmospheric aerosols at mace head, on the west coast of ireland (53 degrees $19^{\prime} \mathrm{n}, 9$ degrees 54'w), Atmos. Environ., 36, 4479-4490, 2002.

Kundu, S., Kawamura, K., Andreae, T. W., Hoffer, A., and Andreae, M. O.: Diurnal variation in the water-soluble inorganic ions, organic carbon and isotopic compositions of total carbon and nitrogen in biomass burning aerosols from the lba-smocc campaign in rondônia, brazil, J. Aerosol Sci., 41, 118-133, 2010a.

Kundu, S., Kawamura, K., Andreae, T. W., Hoffer, A., and Andreae, M. O.: Molecular distributions of dicarboxylic acids, ketocarboxylic acids and a-dicarbonyls in biomass burning aerosols: implications for photochemical production and degradation in smoke layers, Atmos. Chem. Phys., 10, 2209-2225, doi:10.5194/acp-10-2209-2010, 2010b.

Legrand, M., Preunkert, S., Oliveira, T., Pio, C. A., Hammer, S., Gelencser, A., Kasper-Giebl, A., and Laj, P.: Origin of c-2-c-5 dicarboxylic acids in the european atmosphere inferred from yearround aerosol study conducted at a west-east transect, J. Geophys. Res.-Atmos., 112, D23S07, doi:10.1029/2006jd008019, 2007.

Ling, T. Y. and Chan, C. K.: Partial crystallization and deliquescence of particles containing ammonium sulfate and dicarboxylic acids, J. Geophys. Res., 113, D14205, doi:10.1029/2008jd009779, 2008.

Low, R. D. H.: A generalized equation for the solution effect in droplet growth, J. Atmos. Sci., 26, 608-610, 1969.

Malm, W. C. and Kreidenweis, S. M.: The effects of models of aerosol hygroscopicity on the apportionment of extinction, Atmos. Environ., 31, 1965-1976, doi:10.1016/s13522310(96)00355-x, 1997.

Marcolli, C. and Krieger, U. K.: Phase changes during hygroscopic cycles of mixed organic/inorganic model systems of tropospheric aerosols, J. Phys. Chem. A, 110, 1881-1883, 2006 a.

Marcolli, C. and Krieger, U. K.: Phase changes during hygroscopic cycles of mixed organic/inorganic model systems of tropospheric aerosols, J. Phys. Chem. A, 110, 1881-1893, doi:10.1021/jp0556759, 2006b.

Massling, A., Wiedensohler, A., Busch, B., Neusüß, C., Quinn, P., Bates, T., and Covert, D.: Hygroscopic properties of different aerosol types over the Atlantic and Indian Oceans, Atmos. Chem. Phys., 3, 1377-1397, doi:10.5194/acp-3-1377-2003, 2003.

Massling, A., Leinert, S., Wiedensohler, A., and Covert, D.: Hygroscopic growth of sub-micrometer and one-micrometer aerosol particles measured during ACE-Asia, Atmos. Chem. Phys., 7, 3249-3259, doi:10.5194/acp-7-3249-2007, 2007.

McDonald, J. E.: Erroneous cloud-physics applications of raoult's law, J. Meteorol., 10, 68-70, 1953.

McFiggans, G., Artaxo, P., Baltensperger, U., Coe, H., Facchini, M. C., Feingold, G., Fuzzi, S., Gysel, M., Laaksonen, A., Lohmann, U., Mentel, T. F., Murphy, D. M., O’Dowd, C. D., Snider, J. R., and Weingartner, E.: The effect of physical and chemical aerosol properties on warm cloud droplet activation, Atmos. Chem. Phys., 6, 2593-2649, doi:10.5194/acp-6-2593-2006, 2006.

Mensah, A. A., Buchholz, A., Kiendler-Scharr, A., and Mentel, T. F.: Chemical and physical properties of oxalic acid and oxalate aerosol particles, European Aerosol Conference 2009, Karlsruhe, 2009.

Metzger, S., Mihalopoulos, N., and Lelieveld, J.: Importance of mineral cations and organics in gas-aerosol partitioning of reactive nitrogen compounds: case study based on MINOS results, Atmos. Chem. Phys., 6, 2549-2567, doi:10.5194/acp-6-25492006, 2006.

Mircea, M., Facchini, M. C., Decesari, S., Cavalli, F., Emblico, L., Fuzzi, S., Vestin, A., Rissler, J., Swietlicki, E., Frank, G., Andreae, M. O., Maenhaut, W., Rudich, Y., and Artaxo, P.: Importance of the organic aerosol fraction for modeling aerosol hygroscopic growth and activation: a case study in the Amazon Basin, Atmos. Chem. Phys., 5, 3111-3126, doi:10.5194/acp-53111-2005, 2005.

Pandis, S. N., Wexler, A. S., and Seinfeld, J. H.: Dynamics of tropospheric aerosols, J. Phys. Chem., 99, 9646-9659, 1995.

Peng, C. G. and Chan, C. K.: The water cycles of water-soluble organic salts of atmospheric importance, Atmos. Environ., 35, 1183-1192, 2001.

Peng, C., Chan, M. N., and Chan, C. K.: The hygroscopic properties of dicarboxylic and multifunctional acids: Measurements and unifac predictions, Environ. Sci. Technol., 35, 4495-4501, 2001.

Rissman, T. A., Varutbangkul, V., Surratt, J. D., Topping, D. O., McFiggans, G., Flagan, R. C., and Seinfeld, J. H.: Cloud condensation nucleus $(\mathrm{CCN})$ behavior of organic aerosol particles generated by atomization of water and methanol solutions, Atmos. Chem. Phys., 7, 2949-2971, doi:10.5194/acp-7-2949-2007, 2007.

Rozaini, M. Z. H. and Brimblecombe, P.: The solubility measurements of sodium dicarboxylate salts; sodium oxalate, malonate, succinate, glutarate, and adipate in water from $t=(279.15$ to 358.15) $k$, Journal of Chemical Thermodynamics, 41, 980-983, 2009.

Saxena, P. and Hildemann, L. M.: Water-soluble organics in atmo- 
spheric particles: A critical review of the literature and application of thermodynamics to identify candidate compounds, J. Atmos. Chem., 24, 57-109, 1996.

Seinfeld, J. H. and Pandis, S. N.: Atmospheric chemistry and physics: From air pollution to climate change, JOHN WILEY \& SONS, INC, New York, 1998.

Sjogren, S., Gysel, M., Weingartner, E., Baltensperger, U., Cubison, M. J., Coe, H., Zardini, A. A., Marcolli, C., Krieger, U. K., and Peter, T.: Hygroscopic growth and water uptake kinetics of twophase aerosol particles consisting of ammonium sulfate, adipic and humic acid mixtures, J. Aerosol Sci., 38, 157-171, 2007.

Sloane, C. S. and Wolff, G. T.: Prediction of ambient lightscattering using a physical model responsive to relative-humidity - validation with measurements from detroit, Atmos. Environ., 19, 669-680, 1985.

Smith, J. N., Barsanti, K. C., Friedli, H. R., Ehn, M., Kulmala, M., Collins, D. R., Scheckman, J. H., Williams, B. J., and McMurry, P. H.: Observations of aminium salts in atmospheric nanoparticles and possible climatic implications, P. Natl. Acad. Sci. USA, 107, 6634-6639, 2010.

Stokes, R. H. and Robinson, R. A.: Interactions in aqueous nonelectrolyte solutions. I. Solute-solvent equilibria, J. Phys. Chem., 70, 2126-2130, 1966.

Svenningsson, B., Rissler, J., Swietlicki, E., Mircea, M., Bilde, M., Facchini, M. C., Decesari, S., Fuzzi, S., Zhou, J., Mønster, J., and Rosenørn, T.: Hygroscopic growth and critical supersaturations for mixed aerosol particles of inorganic and organic compounds of atmospheric relevance, Atmos. Chem. Phys., 6, 1937-1952, doi:10.5194/acp-6-1937-2006, 2006.

Swietlicki, E., Hansson, H. C., Hameri, K., Svenningsson, B., Massling, A., McFiggans, G., McMurry, P. H., Petaja, T., Tunved, P., Gysel, M., Topping, D., Weingartner, E., Baltensperger, U., Rissler, J., Wiedensohler, A., and Kulmala, M.: Hygroscopic properties of submicrometer atmospheric aerosol particles measured with h-tdma instruments in various environments - a review, Tellus B, 60, 432-469, 2008.

Tang, I. N. and Munkelwitz, H. R.: Water activities, densities, and refractive-indexes of aqueous sulfates and sodium-nitrate droplets of atmospheric importance, J. Geophys. Res.-Atmos., 99, 18801-18808, 1994.

Topping, D. O., McFiggans, G. B., and Coe, H.: A curved multicomponent aerosol hygroscopicity model framework: Part 2 Including organic compounds, Atmos. Chem. Phys., 5, 12231242, doi:10.5194/acp-5-1223-2005, 2005.
Trebs, I., Metzger, S., Meixner, F. X., Helas, G. N., Hoffer, A., Rudich, Y., Falkovich, A. H., Moura, M. A. L., da Silva, R. S., Artaxo, P., Slanina, J., and Andreae, M. O.: The nh4+-no3-clso42-h2o aerosol system and its gas phase precursors at a pasture site in the amazon basin: How relevant are mineral cations and soluble organic acids?, J. Geophys. Res.-Atmos., 110, D07303, doi:10.1029/2004JD005478, 2005.

Wex, H., Ziese, M., Kiselev, A., Henning, S., and Stratmann, F.: Deliquescence and hygroscopic growth of succinic acid particles measured with lacis, Geophys. Res. Lett., 34, L17810, doi:10.1029/2007g1030185, 2007.

Wise, M. E., Surratt, J. D., Curtis, D. B., Shilling, J. E., and Tolbert, M. A.: Hygroscopic growth of ammonium sulfate/dicarboxylic acids, J. Geophys. Res., 108, 4638, doi:10.1029/2003JD003775, 2003.

Yao, X. H., Fang, M., Chan, C. K., Ho, K. F., and Lee, S. C.: Characterization of dicarboxylic acids in pm 2.5 in hong kong, Atmos. Environ., 38, 963-970, 2004.

Yeung, M. C. and Chan, C. K.: Water content and phase transitions in particles of inorganic and organic species and their mixtures using micro-raman spectroscopy, Aerosol Sci. Technol., 44, 269 280, doi:10.1080/02786820903583786, 2010.

Zardini, A. A., Sjogren, S., Marcolli, C., Krieger, U. K., Gysel, M., Weingartner, E., Baltensperger, U., and Peter, T.: A combined particle trap/HTDMA hygroscopicity study of mixed inorganic/organic aerosol particles, Atmos. Chem. Phys., 8, 55895601, doi:10.5194/acp-8-5589-2008, 2008.

Zhang, Q., Jimenez, J. L., Canagaratna, M. R., Allan, J. D., Coe, H., Ulbrich, I., Alfarra, M. R., Takami, A., Middlebrook, A. M., Sun, Y. L., Dzepina, K., Dunlea, E., Docherty, K., DeCarlo, P. F., Salcedo, D., Onasch, T., Jayne, J. T., Miyoshi, T., Shimono, A., Hatakeyama, S., Takegawa, N., Kondo, Y., Schneider, J., Drewnick, F., Borrmann, S., Weimer, S., Demerjian, K., Williams, P., Bower, K., Bahreini, R., Cottrell, L., Griffin, R. J., Rautiainen, J., Sun, J. Y., Zhang, Y. M., and Worsnop, D. R.: Ubiquity and dominance of oxygenated species in organic aerosols in anthropogenically-influenced northern hemisphere midlatitudes, Geophys. Res. Lett., 34, L13801, doi:10.1029/2007GL029979, 2007. 